\title{
Health personnel, family relationships and codependency of psychoactive substances: a phenomenological approach
}

\author{
Pessoal de saúde, relações familiares e codependência de substâncias psicoativas: uma abordagem fenomenológica
}

Personal de salud, relaciones familiares y codependencia de sustancias psicoactivas: un enfoque fenomenológico

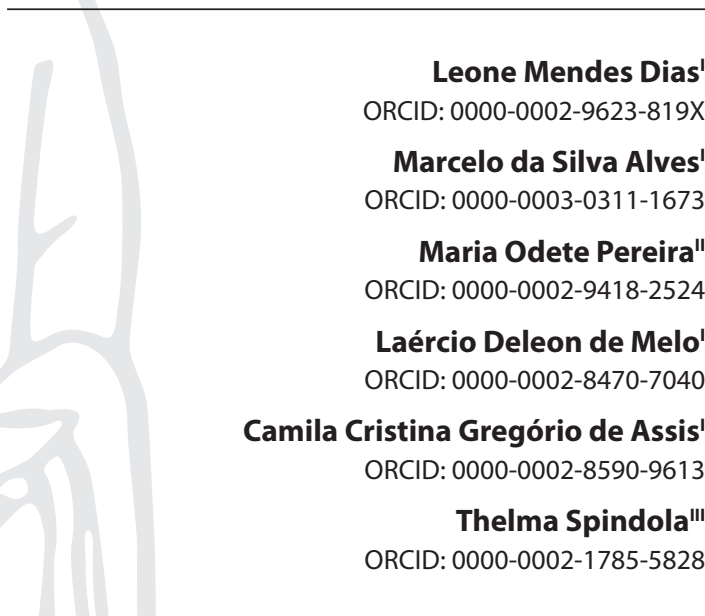

'Universidade Federal de Juiz de Fora. Juiz de Fora, Minas Gerais, Brazil.

"Universidade Federal de Minas Gerais. Belo Horizonte, Minas Gerais, Brazil.

I'Universidade do Estado do Rio de Janeiro. Rio de Janeiro, Rio de Janeiro, Brazil.

How to cite this article: Dias LM, Alves MS, Pereira MO, Melo LD, Assis CCG Spindola T. Health personnel, family relationships and codependency of psychoactive substances: a phenomenological approach.

Rev Bras Enferm. 2021;74(1):e20200309. doi: http://dx.doi.org/10.1590/0034-7167-2020-0309

\section{Corresponding author:}

Leone Mendes Dias

E-mail: leone.mendes@hotmail.com

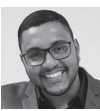

EDITOR IN CHIEF: Dulce Barbosa ASSOCIATE EDITOR: Fátima Helena Espírito Santo

Submission: 06-03-2020

Approval: 09-13-2020

\section{ABSTRACT}

Objectives: to reflect on the daily life of family members dependent on psychoactive substances and the role of health professionals in Primary Care. Methods: a descriptive investigation outlined in Maffesoli's phenomenological approach, carried out at a Basic Health Unit in Minas Gerais with eight family members dependent on psychoactive substances. Sociodemographic characterization data and in-depth interviews were collected and analyzed with support of NVivo Pro $11^{\circ}$ software. All ethical and legal aspects were met. Results: physicians were the professionals most mentioned in participants' statements, who took on a dubious role with other health professionals: welcoming (positive perceptions about care received) and neglect (negative perceptions). Final Considerations: dependence on psychoactive substances imposes a burden on persons, their family members and health professionals. The role of establishing good relationships in the triad professionals-users-family members of primary care is inseparable in favor of treatment and preservation of their mental health. Descriptors: Codependency; Family Relations; Substance-Related Disorders; Health Personnel; Primary Health Care.

\section{RESUMO}

Objetivos: refletir sobre o cotidiano dos familiares codependentes de substâncias psicoativas e o papel dos profissionais de saúde na Atenção Básica. Métodos: investigação descritiva delineada na abordagem fenomenológica de Maffesoli, realizada em uma Unidade Básica de Saúde mineira com oito familiares codependentes de substâncias psicoativas. Foram coletados dados de caracterização sociodemográfica e entrevistas em profundidade, que foram analisadas com apoio do software NVivo Pro $11^{\circ}$. Atenderam-se os aspectos ético-legais. Resultados: o profissional mais mencionado no discurso das participantes foi o médico, que assumiu uma dubiedade de papéis junto aos demais profissionais de saúde: de acolhimento (percepções positivas sobre a assistência recebida) e de descaso (percepções negativas). Considerações Finais: a dependência de substâncias psicoativas acarreta ônus à pessoa, aos seus familiares e aos profissionais de saúde. É indissociável o papel do estabelecimento de boas relações na tríade profissionais-usuários-familiares da Atenção Básica em prol do tratamento e preservação da saúde mental dos envolvidos.

Descritores: Codependência; Relações Familiares; Transtornos Relacionados ao Uso de Substâncias; Pessoal de Saúde; Atenção Primária à Saúde.

\section{RESUMEN}

Objetivos: reflexionar sobre el día a día de los familiares dependientes de sustancias psicoactivas y el papel de los profesionales sanitarios en Atención Primaria. Métodos: investigación descriptiva perfilada en el abordaje fenomenológico de Maffesoli, realizada en una Unidad Básica de Salud en Minas Gerais con ocho familiares dependientes de sustancias psicoactivas. Se recolectaron datos de caracterización sociodemográfica y entrevistas en profundidad, que fueron analizadas con el apoyo del software NVivo Pro $11^{\circ}$. Se cumplieron los aspectos éticos y legales. Resultados: el profesional más mencionado en el discurso de los participantes fue el médico, quien asumió un rol dudoso con el resto de profesionales de la salud: acogida (percepciones positivas sobre la asistencia recibida) y desatención (percepciones negativas). Consideraciones Finales: la dependencia de sustancias psicoactivas supone una carga para la persona, sus familiares y los profesionales sanitarios. El papel del establecimiento de buenas relaciones en la tríada profesionales-usuarios-familiares de Atención Primaria es inseparable a favor del tratamiento y preservación de la salud mental de los implicados. Descriptores: Codependencia; Relaciones Familiares; Trastornos Relacionados con Sustancias; Personal de Salud; Atención Primaria de Salud. 


\section{INTRODUCTION}

Dependence on Psychoactive Substances (PAS) is configured in the current scenario as a serious public health problem worldwide. This is characterized by the situation in which a person depends on continuous use of drugs as a means of escape from unpleasant situations in their daily lives, or to feel relieved of their tendencies, having no control over PAS consumption, despite all the disorders personal injury and damage to acquired social and interpersonal relationships ${ }^{(1-2)}$.

The worldwide report on PAS abuse estimates that \pm 250 million people have disorders due to drug use, corresponding to $5 \%$ of adults worldwide. This alarming problem is aggravated when 30 million people live with some type of mental suffering resulting from PAS use. It is also worth mentioning the high mortality rates ( 52 thousand deaths in 2015)(3) and the number of new cases of infections by the Human Immunodeficiency Virus (HIV) and hepatitis C, acquired sexually and/or due to injectable drug use ${ }^{(3-4)}$.

In this context, the role of family members in the recovery of drug users is essential; however, the exhaustion experienced daily exposes them to physical and psychological vulnerabilities. For several moments, they feel powerless due to little information received and/or perceived unpreparedness due to low support network received to strengthen their coping strategies. This justifies the fact that family members become potential "patients" due to the risk of being affected by biopsychosocial comorbidities, such as codependency ${ }^{(5)}$.

Codependency, sentimental or emotional dependence occurs due to relational situations developed between family members and PAS dependents. There is an inability to sustain relational situations and maintain a linearity of intrinsic/extrinsic relationships, collaborating with harm to codependent people ${ }^{(6)}$. The daily experience is permeated by psychological suffering and tensions, in addition to lack of professional guidance perceived as capable of expanding the possibility of personal illness linked to codependency ${ }^{(7)}$.

Primary Health Care (PHC) is the priority gateway to health services for people dependent on PAS and their codependent family members, and nurses are a strategic element in the front line of Primary Care (PC) services ${ }^{(8-9)}$. Thus, reflections on the role of these professionals in managing care for family members dependent on PAS are necessary. Most of demands presented took on a subjective character that will depend on professional strategies, such as qualified and sensitive listening, holistic view, welcoming and humanization, aimed at establishing the therapeutic link in the triad nurses/users/ family. Through these needs, nurses must plan actions that seek to reinforce coping strategies and promote quality of life ${ }^{(10)}$.

In compliance with the different daily situations in interpersonal relationships in the triad users/ family members/ health professionals in coping with PAS dependence justified the conduct of this investigation. It is also worth mentioning an approximation of the investigated object to the theme "Psychiatric Nursing and Mental Health". The results of this study contribute to reflections on the current overview of psychic suffering of addicts, their codependent family members and their relationships with health and nursing professionals with regard to working conditions and/ or daily relationships established in interpersonal relationships and assistance related to professionals-addicts-family.

Therefore, the following research question was elaborated: what is the role of $\mathrm{PC}$ health professionals in relation to the daily lives of family members dependent on PAS? Therefore, the object outlined in this investigation was the daily life of family members dependent on PAS and the role of health professionals in PC.

\section{OBJECTIVES}

To reflect on the daily life of family members dependent on psychoactive substances and the role of health professionals in PC.

\section{METHODS}

\section{Ethical aspects}

All ethical and legal research requirements in human beings were met, and the matrix investigation was approved on 01/30/2018. The participants'acquiescence expressed by signing the Informed Consent Form (ICF) after clarifying objectives, research purposes and potential risks/benefits of their participation. Anonymity was guaranteed by establishing codenames (e.g., Abigail).

\section{Type of study}

This is a descriptive qualitative investigation outlined in the phenomenological approach according to Michel Maffesoli's framework. Such an approach allows researchers to understand the phenomena through an existentialist logic, which takes into account not only the moment, but a whole daily history that is unveiled every day, at every moment. It also allows the researcher to improve his way of living, as well as orienting him towards an expertise in common phenomena, but never seen in their essence and uniqueness ${ }^{(11-12)}$. Consolidated criteria for Reporting Qualitative Research (COREQ) were met.

\section{Methodological procedures}

The collection tool was structured in: 1) sociodemographic characterization; 2) individual in-depth interview with audio recording; 3) field diary containing records of observations and relevant content, made immediately after the end of each interview, according to the interviewer's considerations during data collection.

\section{Study setting}

This research was carried out in a Basic Health Unit (BHU) in Zona da Mata Mineira, Brazil. It is a health region covered by the Family Health Strategy (FHS) of Unified Health System (SUS Sistema Único de Saúde). The estimated population of the area is 6,612 people with socioeconomic vulnerabilities, and high levels of violence associated with drug trafficking ${ }^{(13)}$.

\section{Data source}

Family members of PAS dependents over 18 were included. Persons who are not the primary caregivers of persons dependent on PAS, who do not live with dependents and who express a desire to interrupt their participation or postpone collection schedule by $\geq$ three approaches were excluded.

Potential participants were recruited by the main researcher through an individual invitation at home. Convenience sampling 
took place through a previous registration of 20 PAS dependents belonging to the area covered by the investigated BHU. There were 12 losses justified by the refusal of these codependent family members, including eight $(\mathrm{N}=08)$ participants.

\section{Data collection and organization}

They were carried out by one of the researchers, with a master's degree in nursing, previously trained, who built previous bonds with potential participants, motivated by his insertion in home visits carried out with professionals, being recognized by potential participants as a member of the BHU staff. This favored the approach required by Maffesoli's in-depth and comprehensive individual interview.

These were guiding questions previously elaborated by the researchers based on the theoretical-methodological frameworks adopted and the intended research objective: what is the daily life like for you living with a chemical dependent family member and the care directed to him/her? Given this problem involving your dependent family member, how do you assess the support provided by health professionals and services offered by BHU? Tell me about an experience involving you or someone with whom you have a relationship about the role of $\mathrm{BHU}$ health professionals in assisting drug addicts and their families.

Individual in-depth interviews, in a unique approach with audio recording (duration of \pm 60 minutes), took place in February and July 2018 , with the durability of six months of collection being combined by the scheduling difficulties on the part of Community Health Workers. Open Data Kit (ODK) 2.0 was used to record the characterization variables and field diary recorded contents immediately at the end of the recorded interview. This strategy reduced data transcription bias or omission of information ${ }^{(14)}$.

\section{Data analysis}

Characterization data were treated in Statistical Package for the Social Sciences (SPSS), version 24 and analyzed with descriptive statistics (central tendency and dispersion). The contents of the interviews were consolidated and analyzed, through units of analysis systematized in a comprehensive perspective of everyday life. To capture the phenomenon investigated, from an individual perspective, the phases of "intuition" and "metaphor" were followed, so that the phenomenological approach would occur with theoretical consistency, aiming at understanding the human being in his complex existential integrality in specific view of participants, avoiding researchers' bias or assumptions ${ }^{(11-12)}$.

Analysis of the recorded contents, after its full transcription, was carried out in order to favor an approximation, assimilation and understanding of the codependent's daily life when living with a family member dependent on PAS and their relationships with health professionals in PHC. Treatment of participants' statements occurred with support of NVivo Pro $11^{\circ}$ with the establishment of analysis categories (units of record and analysis) based on coders, definition of the themes emerging from the data.

Theoretical density was confirmed by the repetition and frequency with which contents emerged and absence of new information complementary to the investigated object, thus expressing data saturation. This was confirmed by its ability to reflect, in quantity and intensity, the multiple dimensions of the investigated phenomenon, ensuring quality and integration ${ }^{(15)}$.

\section{RESULTS}

The participants' sociodemographic profile was: eight (100\%) women with an average age of 56 years (range from 33 to 72 years); self-declared skin color - four (50\%) black and four (50\%) white; marital status - five (62.5\%) were married, two (25\%) were widows and one (12.5\%) was single; education - four (50\%) had elementary school, two (25\%) had high school and two (25\%) had completed higher education; profession - five (62.5\%) were housewives, two (25\%) were retired and one $(12.5 \%)$ worked in commerce; religion - six (75\%) were Catholic, one $(12.5 \%)$ was evangelical and one (12.5\%) was a spiritist. Regarding the degree of kinship with PAS dependents, three (37.5\%) were grandparents, two (25\%) were mothers, two (25\%) were sisters and one (12.5\%) was a wife.

Regarding the perception of family members codependent of PAS in relation to the positioning/performance of health professionals in PC, in the face of the problem of family coping in daily living with an addict, dissatisfaction was evidenced in relation to professional support, considered flawed, mechanistic, superficial and non-resolving. Participants highlighted failures in welcoming professionals from $\mathrm{PC}$, health care at $\mathrm{BHU}$ with neglect and absence of humanization, ineffective active search and difficulties in accessing services. These factors corroborate the poor view of SUS and justify the search for private health plans.

The most mentioned professional was the physician, who took on in participants' statements a dubious role: welcoming (positive perceptions about the assistance received) and neglect (negative perceptions about the assistance received) (Chart 1). However, a professional, here codenamed "Angel", was appointed by participants as a welcoming physician. It is important to note that this professional, in addition to being a family physician, was a specialist in psychiatry. This professional was characterized as being a "nurturing" for participants and stood out in statements as welcoming, caring, with active and qualified listening, sensitive and with a different look for people. Some participants also mentioned receiving support from health services outside $\mathrm{BHU}$, with technical guidance in a subjective and welcoming approach.

In relation to neglect reported by participants, in their discourse, lack of support and the feeling of lack of welcoming prevailed. They reported a superficial reception, informed that they do not like to "go to the physician", and the rules for "renewing prescriptions" proved to be disgusting in relation to mechanized and standardized care in health service. The neglect and helplessness on the part of some professionals, who, according to them, acted indifferently and with total disrespect towards users, justifying their feelings of discomfort, breaking a professional-user bond and also supported for a worsened health problem picture, weakening the daily coping process. Such situations contributed to bond removal and breaking in the triad professional-adctofamily in PC services.

Chart 1 presents the comprehensive phenomenological analysis resulting from in-depth individual interview. 
Chart 1 - Representative scheme of the comprehensive phenomenological analysis according to the eight psychoactive substances codependent family members, Brazil, 2018

\begin{tabular}{|c|c|}
\hline 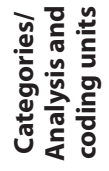 & Comprehensive Phenomenological Analysis \\
\hline 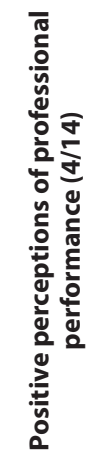 & $\begin{array}{l}\text { We can identify Dr. Angel, you know! He is very good! He still says to me "Miss X, do what you think is best for living". [...] there at Hiperdia there is a } \\
\text { nurse who says she likes me a lot, and I like her a lot. Then I talk to her a lot! I open up to her a lot. So it's good, right? [...] I go there, consult with that } \\
\text { nurse girl. I like the nurse very much. [...] then I was talking to a nurse, she said "You lost weight, what is it?" Oh, I opened up to her Abigail. Today, } \\
\text { Dr. Angel, I think he knows me, I can see in him truth, care, concern and attention that I did not see in five years. [...] ah, I think it was a human return, } \\
\text { from the person (professional) coming to understand you, giving you attention, I think that Bebel. I think so, because with Dr. Angel, I think he } \\
\text { was still fine [...], because he is a great person to open up [...] I think I don't know if it's because we like the physician, he takes care of us so well, that } \\
\text { you feel ... there are some physicians who stand out for their attention, and he, Angel, is a very caring, very caring person, understand? Bete. Dr. } \\
\text { Angel is a blessing in my life, because he helped not only my brother, but helped me to work because I was getting worse. [...] but, the Angel as a } \\
\text { physician who was my salvation ... he is everything to me, that boy (smiling expression). [...] the physician and the nurse realized that I was getting } \\
\text { very anxious, very nervous, I was crying for something. But I was crying because it was the exhaust valve I was having, you know! [...] mainly to say } \\
\text { "Madam, shall we talk?" Only that! Then, I went into his office and spoke and cried. That was a burden taken from me, so I started to have a light } \\
\text { [...] he was guiding me on how to deal with him, because, although I live with drugs and drinks at home, I didn't know how to deal with it Tuca. }\end{array}$ \\
\hline 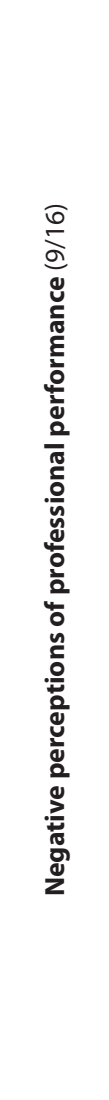 & 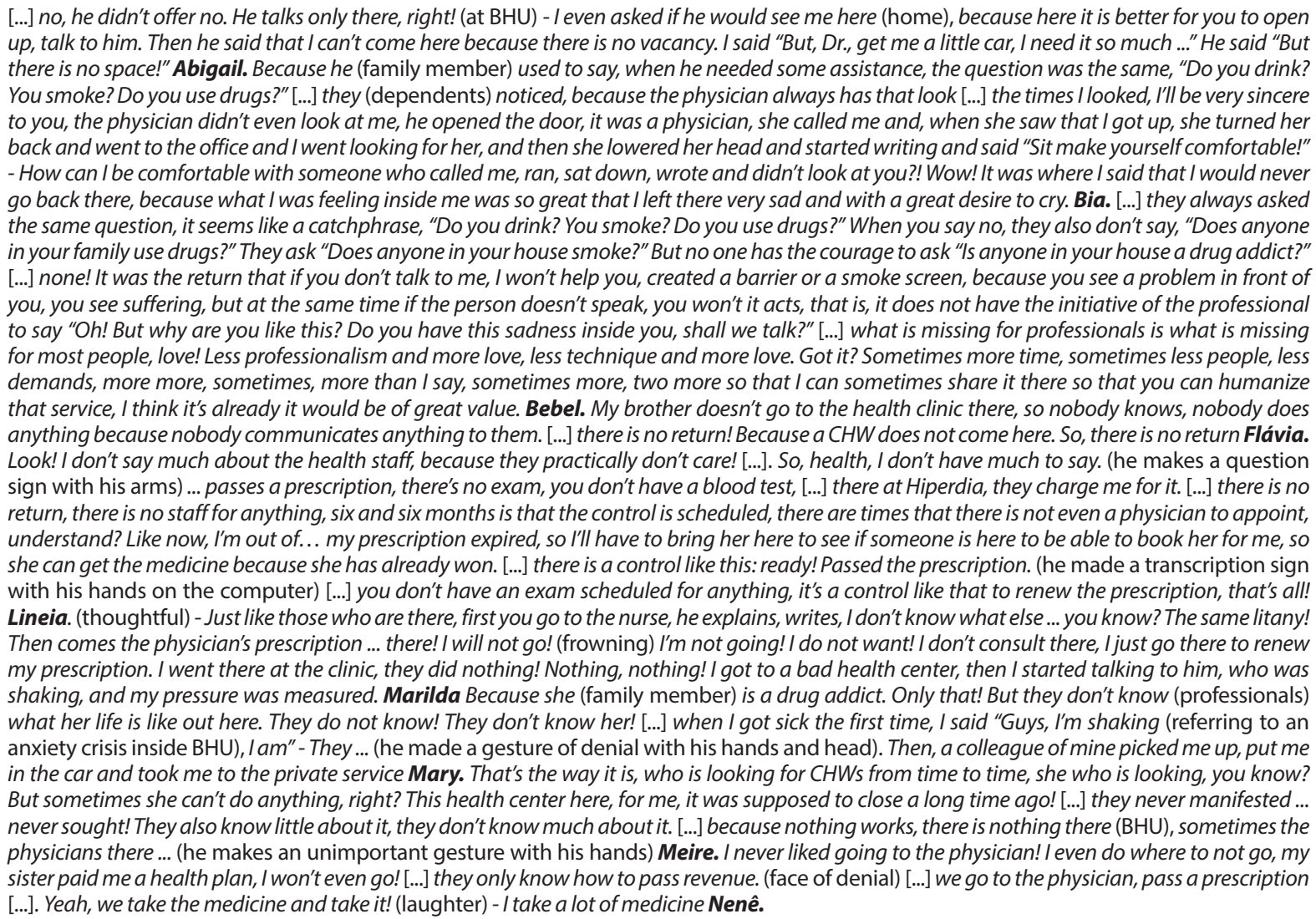 \\
\hline
\end{tabular}

Note: content extracted from NVivo Pro $11^{\circ}$.

Some participants also reported dissatisfaction with care due to other problems faced, such as the long wait for exams, sometimes for years, and/or not performed; difficulty in accessing care due to fragile health conditions, which gave rise to the search for private plans, demands that could be resolved at $\mathrm{BHU}$.

Other situations pointed out by participants concerned superficial care, consultations guided by the biomedical model, with a biological and prescriptive focus. These moments are considered repetitive by stating that, they already knew the service routine, even before it happened, which reflects an idea of reduction, mechanization of service and a superficial approach.

\section{DISCUSSION}

PHC professionals must act according to the objective and subjective demands that involve the complexity of human individuality and focus on the dual aspect of life, collective or individual ${ }^{(1,3,8-9,16)}$. Concomitantly, they must care for the unique care 
of people in their daily lives and innovate in care actions present in the individual context, in order to increase them in social life, so that people can know themselves and be recognized in their entirety $^{(12,16)}$. Interventions must be based on a praxis that does not only address physical problems, but that is capable of giving meaning to people's lives, welcoming them in their demands, with a commitment to positively impact them ${ }^{(16-17)}$.

It should be noted that health professionals, in general, specifically those from PC, mostly demonstrate unpreparedness in handling to deal with the addicted person and their family members, due to failures in the training process, since their graduation. The predominant biologicist training directly impacts professional performance, as a model closely linked to the treatment of disease and physical signs/symptoms. Professionals tend to simple, reductionist, curative actions and are attached to objective, palpable and visible issues. The biomedical model leads professionals so as not to perceive the subjectivities of the people who stand before them, passing through subjective and individual suffering unnoticed ${ }^{(17)}$.

Given the complexity of health services and the rooting of this model, the centrality of the medical figure and his imagery of power exercised over life and death situations, which come with the passage of time and advances in society ${ }^{(17-18)}$. This vision placed medicine at the center of health services, and this happened because their work and their decisions directly impact and define the way people should be led to live, in a biopolitical strategy evidenced since the origin of medicine ${ }^{(10,16,18)}$. Thus, medicine has the power to search, medicalize, separate and influence people, controlling time and space, as well as to assign levels of value to human life, affecting their subjectivities and forms of coping in the bio-psychological and social context in $\mathrm{PC}^{(16,18)}$.

Breaking with the hegemonic/millennial model requires health professionals/services to make joint and interdisciplinary efforts that overcome a reduced vision, rooted in biologicism. It is necessary to value the unsaid/perceived and to praise the uniqueness of the other, releasing prejudices, as well as bringing professionals/users closer, favoring a humanized service, creating bonds, trust and (with) sharing, so that both are improve and develop interpersonal relationships. The direct impacts on the lives of both involve the professional feeling for the subjective dimension, with the ability to accept the suffering of others ${ }^{(19-20)}$.

These characteristics describe an inclination towards the intuition of certain situations, so that professionals are invited to take on an empathetic and supportive attitude towards the other. It is expected that this happens through a horizontal relationship, which allows those involved to become aware of the other's life, to capture elements and essences and to accept in a respectful and sensitive way the subjectivity of the other and their experience, understood through him/herself ${ }^{(11-12)}$. Thus, lines of care are established in favor of valuing life ${ }^{(16)}$.

$P C$ requires professional skills, abilities and qualities to meet objective demands, however subjective skills are essential, such as empathy to fully embrace health service users ${ }^{(8-9,13,16-17)}$. In professional unpreparedness, when accepting demands that involve the complex and dense subjectivity of the other, there are failures in interaction, acceptance and understanding of what led the other to the health service (16-17,19-20). $^{\text {. }}$
Professionals with the ability to welcome the other in a comprehensive and multidimensional way are able to carry out such action through the knowledge of themselves and their work process. When professionals are aware of the meaning of their work, that is, their praxis, and recognize their essence, professional identity, limitations and potential, they become capable of raising awareness and putting themselves in the place of the other, offering dignified service in health with qualified and supportive listening ${ }^{(19)}$

In $\mathrm{PC}$, professionals must be able to correlate care linked to active, integral listening and in accordance with the principles of SUS in order to direct their actions towards an inclusive logic, which is capable of seeking the essence of people ${ }^{(8-9,20)}$. It is noteworthy that professionals who are not able to cast a different look on the other, in an interactionist and emancipatory logic, will execute mechanistic actions, empty, without exchange and without human development ${ }^{(16-18,20)}$.

The interaction in the triad professional-user-family occurs successfully when the interaction is satisfactory for all, experienced through care and reception sustained by mutual respect, by genuine solidarity, in which the opportunity to share moments together is given ${ }^{(2,5-6,21)}$. More than a professional interaction, it is a moment of bonding, knowledge and recognition of the other as a being with potential and limitations capable of establishing a horizontal relationship, which benefits and collaborates for human growth and development ${ }^{(5,19-21)}$.

When people perceive themselves as being seen comprehensively by professionals, they feel happy, satisfied and important, which provides a relationship of security and trust, permeated by the commitment of these people when they feel completely welcomed and supported by the health service $\mathrm{e}^{(2,8-9,16-17,20)}$. On the other hand, clinical management in an objective sphere, centered on the biomedical model, corroborates for professionals to act by segregating the psychological suffering of the biological body ${ }^{(9,16,20)}$. This invalidates multidimensional approaches and reduces users to their pathogenesis, resulting in hostile behaviors in care relationships ${ }^{(16,18,20)}$.

A possible lack of commitment to professional care, associated with the inability to subjective reception, which requires actions that go beyond the expanded clinic, contributes to a negative perception on the part of users, their family and the community regarding health professionals and the service of health. This puts at risk the image of seriousness and commitment of professionals who work to guarantee access to health for the population ${ }^{(17,21-22)}$.

This lack of professional commitment can also weaken the Health Care Network (RAS - Rede de Atenção à Saúde). It aims to realign the SUS in such a way that the health care lines talk to each other and take care of the daily demands faced by the system and proposes effective measures capable of offering health care that approaches the ideal. Therefore, it calls for drastic changes in the existing model, directing actions to meet the population's demands at different levels of health ${ }^{(23)}$.

However, it is worth noting that RAS and the Psychosocial Care Network (Raps) are interdependent lines of care, aimed at dignified care for people in mental distress, and are public health policies to guarantee comprehensive and humanized care for these people. Actions include professional training, permanent 
health education, aiming to reduce communication failures and professional resistance in a logic that escapes biomedical standards ${ }^{(23-24)}$.

Numerous challenges are faced to guarantee universal, egalitarian and equitable health, and these obstacles are configured in the political, social and economic spheres. It is undeniable that, for the effective functioning of services, political interest on the part of governments is necessary. Directly, when PC is not a political priority, there is a cascade reaction of local fragility of RAS as a free public service, since without investments and with a precarious structure, $\mathrm{PC}$ cannot guarantee satisfactory service within the recommended ${ }^{(25)}$.

Realignment in the quality of services and care provided to the population, better working conditions, minimizing work overload, constant training to deal with diverse demands, obtaining intersectoral support for decision making, improvements in referral and counter-referral mechanisms need to be prioritized. The focus should involve health promotion and disease prevention actions as a challenge to be faced by PC, which requires innovative and assertive measures from professionals, despite the deficit in working conditions, material resources/inputs and an insufficient number of trained professionals ${ }^{(19-20,25)}$.

Lack of professionals able to work at PC, which is "basic" only in name, reveals flaws in teaching in all health courses, with plastered curricula, disintegrated disciplines and still focusing on diseases, distanced from the everyday reality of experiences and experiences in loco. This makes professionals unaware of the reality and sometimes does not critically associate theory and reality in a problematic way so that health care could occur safely, resolutely and sparingly ${ }^{(25-26)}$.

However, it is noteworthy that one of the biggest challenges is the effective articulation between PC, person, family and community, since the lack of interaction between them allows the emergence of inequities and inequalities in health, such as the active search, in the FHS, aims at an autonomous service led by the assisted person ${ }^{(9,16,27)}$. However, this is only effective when professionals have commitment, recognition of their professional identity and job satisfaction, which facilitate the overcoming of challenges inherent to PC. Thus, it becomes an active mediator of health promotion and disease prevention actions ${ }^{(7,17,23,27)}$.

It is worth mentioning that, in order to reduce health inequities and delay in care, as well as expand services, the Brazilian National Program for Improving Access and Quality in Primary Care (PMAQ - Programa Nacional de Melhoria do Acesso e da Qualidade da Atenção Básica) was created. This is an initiative to develop proposals that contribute positively to $\mathrm{PC}$, being a driver of health services at the primary level ${ }^{(9)}$.

In health services, users crave a good service from the professional staff, which is positive and actually solves their problem ${ }^{(8-9,28)}$. In a socio-historical-philosophical way, health relationships occurred based on the logic of pious compassion, which emphasizes and strengthens professional power over users, through a relationship that segregates and feeds the fragile person's dependence on professionals ${ }^{(29)}$. A professional-user relationship is proposed in a supportive manner, which values the essence of the human being and is capable of generating exchanges and shares, with an empathic attitude and devoid of interests $s^{(10,17,20,29)}$.
In search of this solidary logic, PC professionals should recognize the welcoming as a unique moment, not being understood as the number of consultations, directions, requests for exams or medicalization. It must be considered that PC has different barriers to care, described above, and that they generate barriers in accessing health services. This corroborates a negative view of users about professionals and services. They do not feel fulfilled/ satisfied and their demands are sometimes not resolved, or are partially resolved and, when fully met, demanded a lot of time and persistence ${ }^{(30)}$.

A holistic approach is necessary, capable of generating a re-characterization of people, in a process of subjectification, affirmation of the identity and potential of the other, mediator so that the people cared for are protagonists of their history, autonomous and able to decide for themselves ${ }^{(28)}$. A strategy that could go against the search and segregationist system that gives values to life and the human condition is knowledge and work through the perspective of the expanded and solidary clinic. Such clinic aims to work people as they are, guaranteeing their process of subjectification, as well as valuing the person as unique and capable of taking responsibility for their own life, being a transforming agent of reality ${ }^{(16-17,20)}$.

The concept of extended clinic should be performed through daily exercise. In view of the complexity and density of the encounter with the other, it is necessary to be able to offer innovative, resolutive and comprehensive responses to their needs in a redirected way through dialogue in the triad professional-user-family ${ }^{(16,25,30)}$.

Health professionals in caring for people in psychological distress or with some subjective demand are sometimes unable to go beyond the physical dimension of being assisted. They have deep anguish because they do not know how to deal with the complexity of the other's subjectivity, they are limited by work overload, impaired qualified listening and difficulties in handling feelings and extraphysical problems that affect users. They use technologies that are considered hard to take care of what is subjective, such as medicalization ${ }^{(31)}$.

The care linked to PC in mental health should promote health and guarantee comprehensive assistance to people, without stigmatizing, harassing, segregating or treating superficially, as such attitudes negatively and directly impact people with mental health care demands, and, in PAS use case, involves more complex situations, such as not understanding it as a disease. Addiction is assimilated as idleness, lack of interest in work and unproductiveness. Dependent people and their families are often marginalized by society as if they were responsible for being and wanting to stay in that situation and, therefore, need the intervention of different sectors of society ${ }^{(24,31)}$.

In relation to PAS users and their family members, health professionals need to show an empathetic position of interest and understanding, with qualified listening aimed at exchanging information and aiming at guaranteeing tools so that they are able to act in daily life. Therefore, professionals put themselves until all treatment possibilities are exhausted, as a mediator and a reference for guidance to the family and community ${ }^{(17,31)}$.

Lack of information arising from professional relationships in the face of a problem corroborates the feeling of helplessness of codependent family members and prevents them from acting 
in an agile and assertive manner, becoming disoriented and stagnant because they do not know how to act. Lack of information related to addiction by professionals, users, family and community contributes to the expansion of the drug addiction chart. In this context, health professionals are expected to face addiction, together with users' family members, with skills such as empathy, welcoming, solidarity, knowledge about treatment through the expanded clinic and resolute and articulate attitudes to other specialized services ${ }^{(19,32)}$.

An effective reception is one capable of generating feelings of satisfaction and relief in users in relation to the demand that led them to seek care, as well as covering other aspects and dimensions that surprised users. They feel comfortable opening up to professionals, as they recognize him not as superior, but as sympathetic to his central problem and willing to accept his subjectivity and guarantee its authenticity and potential with mutual respect and equality. Professionals should mediate the subject's autonomy, granting them knowledge and information for their citizen freedom ${ }^{(31)}$ in accordance with the Brazilian National Humanization Policy (PNH - Política Nacional de Humanização) (33), respecting SUS principles and guidelines with a view to minimizing inequities ${ }^{(8-9,24)}$ through balance between different care technologies (soft, soft-hard and hard) ${ }^{(9,31)}$.

Interdisciplinary staff's work is essential, with emphasis on nurses for having comprehensive skills to provide care to all people with the interdisciplinary staff, at different levels of complexity and profiles of illnesses. In PHC, nursing plays the leadership role vis-à-vis the community and $\mathrm{BHU}$, occupying, in most cases, service management position. It is necessary for nurses to carry out the work process in a systematic way, to overcome bureaucratic demands, to position themselves as responsible for care efficiently, legally based, and to provide the protagonism of care to the assisted person ${ }^{(34)}$.

Among the reasons that lead to dissatisfaction of PC users are long waits for assistance; difficulty in making appointments; limitation of care due to spontaneous demand and situations involving professionals (lack of empathy, inaptitude in welcoming, superficial care, use of hard medicalizing technologies, absence of therapeutic touch) ${ }^{(35)}$.

Users point out professional unpreparedness and lack of motivation to perform welcoming as complications and barriers in accessing health services. Due to the negative perception of welcoming, users tend not to feel satisfied, and, due to the fact that there is an implied power relationship, they tend to be silent and create obstacles for future care due to the negative situations experienced ${ }^{(30-31,35)}$.

On the other hand, a humanized service contributes to a positive perception on the part of users in relation to professionals and the service provided. Qualities such as respect, excitement and motivation of professionals, interest in their demand, eye contact, professional attention to what is being spoken, welcoming body expression, therapeutic touch, service time and efficiency are reported $^{(30-31,33)}$. This attitude should occur from the beginning to the end of the service and include the active search, since users feel satisfied, important, welcomed by the staff, assess the results as affective and generators of well-being ${ }^{(32)}$.

Health actions are more focused on the subjective, promoting a stability in care in a way that complement the tools/technologies used in care, effect welcoming, allow the creation of bonds, facilitate participatory strategic management and co-management care among those involved ${ }^{(32-33)}$. Such management is mediated by a humanized reception that enhances users' autonomy in relation to their own health and their territory, and is close to the comprehensive care idealized by SUS and $\mathrm{PNH}^{(23,33)}$.

The interplay between the different social actors promotes the valorization and strengthening of actions at the PC level, establishing a partnership in the form of welcoming groups and small group initiatives through workshops ${ }^{(8-9)}$. BHU acquires a connection with the community and establishes bonds of trust and loyalty, in which it relates in an interdependent manner, consolidating the principles of SUS and the social importance in health production ${ }^{(30-32)}$.

It is worth emphasizing the peculiarities in relation to caring for PAS dependents and their codependents. Professionals do not feel prepared to accommodate this demand, as it is complex and involves other issues that escape health and enter public security, involving drug trafficking and homicide cases in the territory. This problem corroborates for superficial/punctual professional attitudes, such as not deepening the theme and not investigating the possibility that this is the origin of other comorbidities. Most professionals do not even mention the subject and adopt rapid medicalization measures ${ }^{(16-17,32)}$.

Professional unpreparedness in welcoming family members of addicts corroborates their illness, accentuates health inequities, violates human rights, limits these individuals' access to health ${ }^{(32,34)}$. It is noted that the articulation between specialized staff and PC needs to align itself for an effective, comprehensive, dignified, humanized service, easing the situation experienced by these people and reducing the pre-existing socioeconomic and biopsychosocial vulnerabilities ${ }^{(9,23-24,34)}$.

\section{Study limitations}

One can mention the difficulty of translating these results into another reality that is justified by the qualitative methodological design adopted and the small number of participants, despite the approach of the total eligible population in the investigated scenario.

\section{Contributions to nursing, health, and public policies}

The daily lives of family members with codependency on PAS and the role of health professionals in PC presented provide reflections on new proposals for strategic professional and investigative approaches. They should be able to reduce the negative assessment of relationships established in the triad professional-user-family in order to qualify and facilitate professional care, causing improvements in coping with the disease in a welcoming, humanized, integral and multidimensional way, with respect to the different individual and family singularities.

\section{FINAL CONSIDERATIOS}

The daily life living with dependence on PAS places a burden on users, their codependent family members as well as 
professionals involved. They are multidimensional and can compromise biopsychosocio-spiritual aspects, interpersonal and family relationships.

Establishing therapeutic relationships in the triad professionaluser-family in PC in favor of treatment and preservation of the mental health of those involved was dubiously perceived, with positive and negative perceptions as a necessary and inseparable demand for strategies that deal with humanization, welcoming and inclusion of addicts and their families as protagonists in their care. It is worth mentioning that the position of omission adopted by some professionals in combating PAS use contributes to the joint illness of addicts and codependent family members and community.

\section{REFERENCES}

1. Ministério da Saúde (BR). SAS/DAB. Saúde mental, Departamento de Ações Programáticas Estratégicas. Brasília: MS; 2013.

2. Soccol KLS, Terra MG, Ribeiro DB, Teixeira JKS, Siqueira DF, Mostardeiro SCTS. The routine of family relationships with a substance dependent individual. Cogitare Enfermagem [Internet]. 2014 [cited 2020 May 5];19(01):118-24. Available from: http://www.revenf.bvs.br/pdf/ce/ v19n1/17.pdf

3. United Nations Office on Drugs and Crime, World Drug Report 2017 [Internet]. 2017[cited 2020 May 5]. Available from: https://www.unodc. org/wdr2017/field/Booklet_1_EXSUM.pdf

4. Queiroz CM, Arreguy-Sena C, Krempser P, Leonel M, Melo LD. Triangulação de métodos na representação social: auto punção de drogas em (ex)usuários soropositivos para HIV. Rev Cent O Min. 2014;3(4):1229-47. doi: 10.19175/recom.v0i0.435

5. Braun LM, Zanon LLD, Halpern SCA. A família do usuário de drogas no CAPS: um relato de experiência. Rev SPAGESP [Internet]. 2014[cited 2020 May 5];15(2):122-40. Available from: http://pepsic.bvsalud.org/pdf/rspagesp/v15n2/v15n2a10.pdf

6. Marques AB. Famílias codependentes também precisam de ajuda. In: Âmbito Jurídico [Internet]. 2020[cited 2020 May 5];XX(160). Available from: http://www.ambitojuridico.com.br/site/?n_link=revista_artigos_leitura\&artigo_id=18943\&revista_caderno=14

7. Prata NISS, Groisman D, Martins DA, Rabello ET, Mota FS, Jorge MA, et al. Saúde mental e atenção básica: território, violência e o desafio das abordagens psicossociais. Trab Educ Saúde. 2017;15(01):33-53. doi: 10.1590/1981-7746-sol00046

8. Ministério da Saúde (BR). Política Nacional de Atenção Básica. Brasília (DF); 2012. (Série E. Legislação em Saúde).

9. Ministério da Saúde (BR). Manual Instrutivo para as equipes de Atenção Básica e NASF: Programa Nacional de Melhoria do Acesso e da Qualidade da Atenção Básica (PMAQ). Terceiro ciclo (2015-2017). Brasília: MS; 2017. 89p.

10. Caetano OS, Feltrin JO, Soratto J, Sorrato MT. Conduta do enfermeiro frente aos conflitos éticos e bioéticos em área vulnerável na ESF. Rev Saúde Pesqui. 2016;09(02):349-60. doi: 10.17765/2176-9206.2016v9n2p349-360

11. Maffesoli M. O Conhecimento comum: introdução à sociologia compreensiva. Porto Alegre: Sulina; 2010. 295 p.

12. Nistchke R, Tholl AD, Potrich T, Silva KM, Michelin SR, Laeureano DD. Contributions of Michel Maffesoli's thinking to research in nursing and health. Texto Contexto Enferm. 2017;26(4):1-12. doi: 10.1590/0104-07072017003230017

13. Secretaria de Saúde (BR). Plano Diretor da Atenção Primária em Saúde: projeto de implantação. Juiz de Fora (MG). 2014.

14. Pereira APN, Arreguy-Sena C, Queiroz ABA, Dutra HS, de Melo LD, Krempser P. Representações sociais de enfermeiros da atenção primária sobre registros de enfermagem em prontuários. Enferm Bras. 2019;18(6):759-66. doi: 10.33233/eb.v18i6.3219

15. Minayo MCS. Amostragem e saturação em pesquisa qualitativa: consensos e controvérsias. Rev Pesqui Qualit[Internet]. 2017 [cited 2020 May 5];5(7):1-12. Available from: https://editora.sepq.org.br/index.php/rpq/article/view/82/59

16. Soalheiro N (Org.). Saúde Mental para a atenção básica. Rio de Janeiro: Fiocruz; 2017. 249 p.

17. Laport TJ, Costa PHA, Mota DCB, Ronzani TM. Percepções e práticas dos profissionais da atenção primária à saúde na abordagem sobre drogas. Psicol Teor Pesqui. 2016;32(1):143-50. doi: 10.1590/0102-377222016012055143150

18. Ribeiro ACL, Ferla AA. Como médicos se tornaram deuses: reflexões acerca do poder médico na atualidade. Psicol Rev [Internet]. 2016[cited 2020 May 5];22(2):294-314. Available from: http://pepsic.bvsalud.org/pdf/per/v22n2/v22n2a04.pdf

19. Lira LBS, Santos DS, Neves SJF, Nagliate PC, Lira LBS, Pereira EAT, et al. Access, welcoming and family health strategy: user satisfaction. Rev Enferm UFPE. 2018;12(9):2334-40. doi: 10.5205/1981-8963-v12i9a234878p2334-2340-2018

20. Carnut L. Cuidado, integralidade e atenção primária: articulação essencial para refletir sobre o setor saúde no Brasil. Saúde Debate. 2017;41(115):1177-86. doi: 10.1590/0103-1104201711515

21. Nunes M, Landim FLP (Org.). Saúde Mental na Atenção Básica: política e cotidiano. Salvador: EDUFBA; 2016. 496 p.

22. Lago JN, Silva RR, Costa Silva RR, Gonzaga IA, Gonzaga IA, Campos ACS. Reflexões teóricas em educação em saúde: gestão de enfermagem na atenção básica. Complexitas Rev Fil Tem[Internet]. 2019[cited 2020 May 5];4(1):73-8. Available from: https://www.periodicos.ufpa.br/ index.php/complexitas/article/view/8046

23. Ministério da Saúde (BR). Portaria n. 4.279, de 30/12/2010: estabelece diretrizes para a organização da Rede de Atenção à Saúde no âmbito do Sistema Único de Saúde (SUS). Brasília(DF): MS; 2010. 
24. Ministério da Saúde (BR). Portaria n 3.088, de 23 de dezembro de 2011. Institui a rede de atenção psicossocial para pessoas com sofrimento ou transtorno mental e com necessidades decorrentes do uso de crack, álcool e outras drogas, no âmbito do sistema único de saúde.

25. Soder RF, Santos LE, Oliveira IC, Silva LAA, Peiter CC, Santos JLG. Práticas de enfermeiros na gestão do cuidado na atenção básica. Rev Cuba Enferm [Internet]. 2020[cited 2020 May 5];36(1):e2815. Available from: http://revenfermeria.sld.cu/index.php/enf/article/view/2815/531

26. Mendes TMC, Ferreira TLS, Carvalho YM, Silva LG, Souza CMCL, Andrade FB. Contributions and challenges of teaching-service-community integration. Texto Contexto Enferm. 2020;29:e20180333. doi: 10.1590/1980-265X-TCE-2018-0333

27. Nunes VV, Feitosa LGGC, Fernandes MA, Almeida CAPL, Ramos CV. Primary care mental health: nurses' activities in the psychosocial care network. Rev Bras Enferm. 2020;73(Suppl 1):e20190104. doi: 10.1590/0034-7167-2019-0104

28. Carrapato JFL, Castanheira ERL, Placideli N. Perceptions of primary healthcare professionals about quality in the work process. Saúde Soc. 2018;27(2):518-30. doi: 10.1590/s0104-12902018170012

29. Caponi S. Da compaixão à solidariedade: uma genealogia da assistência médica. Rio de Janeiro: Editora Fiocruz; 2000. 100 p. doi: $10.7476 / 9788575415153$

30. Turci M, Lima e Costa M, Macinko J. Avaliação da Atenção Primária e a percepção do usuário sobre a qualidade da assistência: um estudo em cidade brasileira. APS Rev. 2019;1(1):1-14. doi: 10.14295/aps.v1i1.13

31. Gueterres ÉC, Harter J. Evaluación de acogida como primer contacto en atención primaria en Rio Grande do Sul. Tesela Lider Gestión, 2020;(27):e12322. Available from: http://ciberindex.com/c/ts/e12322

32. Santos FF, Ferla AA. Saúde mental e atenção básica no cuidado aos usuários de álcool e outras drogas. Interface. 2017;21(63):833-44. doi: 10.1590/1807-57622016.0270

33. Ministério da Saúde (BR). Política Nacional de Humanização: HUMANIZASUS. MS: Brasília. 2003.

34. Farias LMS, Azevedo AK, Silva NMN, Lima JM. Nurses and the assistance to drug users in basic care services. Rev Enferm UFPE. 2017;11(Supl. 7):2871-80. doi: 10.5205/1981-8963-v11i7a23467p2871-2880-2017

35. Gomide MFS, Pinto IC, Bulgarelli AF, Santos ALP, Gallardo MPS. User satisfaction with primary health care: an analysis of access and care. Interface. 2018;22(65):1-19. doi: 10.1590/1807-57622016.0633 